\title{
A tin-bismuth alloy electrode for cathodic stripping voltammetric determination of iron in coastal waters
}

Article in Analytical methods · May 2015

DOI: 10.1039/C5AY00886G

CITATION

1

5 authors, including:

\section{Mingyue Lin}

Chinese Academy of Sciences

15 PUBLICATIONS 80 CITATIONS

SEE PROFILE
READS

28

Dawei Pan

Chinese Academy of Sciences

33 PUBLICATIONS 221 CITATIONS

SEE PROFILE 


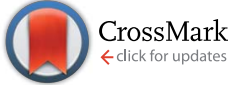

Cite this: Anal. Methods, 2015, 7, 5169

\title{
A tin-bismuth alloy electrode for the cathodic stripping voltammetric determination of iron in coastal waters
}

\author{
Mingyue Lin, ${ }^{\text {ab }}$ Dawei Pan, ${ }^{* a}$ Xueping Hu, ${ }^{\text {ab }}$ Fei Li $^{c}$ and Haitao Han ${ }^{a}$ \\ We employed a home-made tin-bismuth alloy electrode (SnBiE) as the working electrode with 1-(2- \\ piridylazo)-2-naphthol (PAN) as the complexing ligand to detect trace iron. This method is based on the \\ cathodic reduction of Fe(III)-PAN complex to Fe(॥)-PAN complex at the SnBiE by using adsorptive \\ cathodic stripping voltammetry. The experimental parameters, such as the $\mathrm{pH}$ value, concentration of \\ buffer solution, accumulation potential, accumulation time and the concentrations of PAN, were \\ optimized, and the interference by other ions was investigated in detail. The response of Fe(III) was linear \\ in the range of $1 \mathrm{nM}$ to $900 \mathrm{nM}$ with a detection limit of $0.2 \mathrm{nM}$ (after $60 \mathrm{~s}$ of accumulation, $s / n=3$ ). \\ This method can also be applied to the determination of iron in coastal rivers and seawater with \\ satisfactory results.
}

Received 5th April 2015

Accepted 13th May 2015

DOI: 10.1039/c5ay00886g

www.rsc.org/methods expensive for the ultra-trace determination of iron and can suffer from interferences. ${ }^{15}$ Moreover, the current need for expensive and bulky devices also restrict their use in laboratorybased determinations and on-site experiments. In comparison, stripping analysis is recognized as an extremely sensitive electrochemical technique for iron determination due to its advantages of relatively low cost, use of portable instruments, and high sensitivity. ${ }^{16}$ Cathodic stripping voltammetry (CSV) based on the mercury electrode ${ }^{17-22}$ is the most widely used electrochemical technique for iron determination in natural water and seawater. Several ligands such as catechol, ${ }^{17} 1$ nitroso-2-naphtol (NN), ${ }^{18,19}$ 2-(2-thiazolyazo)-p-cresol (TAC), ${ }^{20}$ and 2,3-dihydroxynaphtalene (DHN) ${ }^{21,22}$ have been developed. However, the well-known toxicity and handling inconveniences of mercury have recently restricted its use. Because the bismuthbased electrode was introduced as a favorable alternative mercury-free electrode material by Wang's group, ${ }^{23,24}$ it has been widely used in the stripping electroanalytical determination of metal ions due to its low toxicity and similar properties to the $\mathrm{Hg}$ electrode. ${ }^{25}$ The bismuth-film electrode (BiFE) has been successfully applied in trace iron determination with the aid of ligands such as 1-(2-piridylazo)-2-naphthol (PAN) ${ }^{26}$ and triethanolamine (TEA). ${ }^{27}$ However, bismuth film is not homogeneous, and because the morphology depends on the plating potential and substrate electrode, this has a profound effect on the nucleation and growth of the bismuth deposit. ${ }^{28}$ Lately, tin has been proposed as a new electrode material based on the mechanism of the bismuth-film electrode because the positions of tin and bismuth are cater-cornered in the elementary periodic table and tin may have similar characters to bismuth. ${ }^{29}$ Moreover, tin is also an environmentally friendly material with a very low toxicity. ${ }^{30}$ It has been successfully applied in the 
determination of trace metals such as $\mathrm{Cr}^{3+}, \mathrm{Cd}^{2+}, 29,31,33$ $\mathrm{Zn}^{2+},{ }^{31,32} \mathrm{~Pb}^{2+},{ }^{32} \mathrm{Cu}^{2+},{ }^{32}$ and $\mathrm{Ti}^{+} .^{32}$ Moreover, the tin/bismuth film electrode, which was modified by in situ depositing tin and bismuth on a poly( $p$-aminobenzene sulfonic acid)-coated glassy carbon electrode, showed a better stripping current response than the traditional bismuth and tin film electrodes. ${ }^{33}$ However, the preparation of this type of tin/bismuth film electrode is relatively complex. Recently, the tin-bismuth alloy electrode ( $\mathrm{SnBiE}$ ) has been reported in our lab to have better electrochemical properties than BiFEs and has been successfully applied in $\mathrm{Zn}^{2+}$ and $\mathrm{Cd}^{2+}$ analysis. ${ }^{34,35}$

In the present work, the $\mathrm{Fe}$ (III)/Fe(II)-PAN complex, in a slightly acidic supporting electrolyte of acetate, was studied using the home-made SnBiE as the working electrode and adsorptive cathodic stripping voltammetry. The experimental parameters, including the $\mathrm{pH}$ value and concentration of acetate buffer, the accumulation potential and time, and the concentrations of PAN, were investigated in detail. In addition, the practical application of SnBiE was successfully carried out for the total dissolved iron in coastal waters. Moreover, the results achieved using $\mathrm{SnBiE}$ were compared with BiFEs and other electrochemical methods, which showed that SnBiE has a better response and practical use in iron determination.

\section{Experimental section}

\section{Reagents and apparatus}

All chemicals used were of analytical grade purity, except $\mathrm{HCl}$, which was a guaranteed reagent. Aqueous solutions were made with deionized water (18.2 $\mathrm{M} \Omega \mathrm{cm}$ specific resistance) produced by Pall Cascada's laboratory water system. Standard stock solutions of $\mathrm{Cu}^{2+}, \mathrm{Zn}^{2+}, \mathrm{Cd}^{2+}, \mathrm{Cr}^{3+}, \mathrm{Hg}^{2+}, \mathrm{As}^{3+}, \mathrm{Ag}^{+}, \mathrm{Al}^{3+}, \mathrm{Ni}^{2+}$, $\mathrm{Pb}^{2+}, \mathrm{Mg}^{2+}, \mathrm{Mn}^{2+}, \mathrm{Co}^{2+}$, humic substances (HS), ethylene diamine tetraacetic acid (EDTA), sodium dodecyl benzene sulfonate (SDBS), cetyltrimethyl ammonium bromide (CTAB), and $\mathrm{NaCl}$ were obtained from Sinopharm Chemical Reagent and diluted as required. Iron standard solutions were prepared from the chloride of $\mathrm{Fe}^{3+}$ (Sinopharm Chemical Reagent Co., Ltd., China.) in 0.1 M HCl. 0.1 M acetate buffer solutions (pH 3.5-5.5) were prepared with sodium acetate and acetic acid.

All the electrochemical experiments were performed using a CHI 660D electrochemical work station (Shanghai CH Instruments, Shanghai, China) with a conventional three-electrode system. A SnBiE served as the working electrode, a $\mathrm{Ag} / \mathrm{AgCl}$ (saturated $\mathrm{KCl}$ solution) was used as the reference electrode, and a platinum foil counter electrode was employed as the auxiliary electrode. Inductively coupled plasma-mass spectrometry (ICP-MS, ELAN DRCII, Perkin Elmer Instruments, USA) was used for the comparative testing. All the experiments were conducted at room temperature $\left(25^{\circ} \mathrm{C}\right)$.

\section{Preparation of real coastal water samples}

River water samples were collected from two local rivers that flow into the Bohai Sea (Jiehe and Xiaoqinghe, Shandong Province). Seawater samples were collected from the Bohai Sea. The samples were filtered by $0.45 \mu \mathrm{m}$ membrane filters after collection, then saved in FEP bottles and kept at $4{ }^{\circ} \mathrm{C}$ until determination. To remove the organic complexes and liberate iron from the complexes with natural ligands, the total dissolved iron in the water samples was determined after the UVdigestion (30 min, $500 \mathrm{~W}$, Metrohm MVA-UV 705) at pH less than 2.0.

\section{Preparation of $\mathrm{SnBiE}$}

Sn-Bi alloy wires ( $\mathrm{Sn}: \mathrm{Bi}, 42: 58 \mathrm{wt} \%, 1 \mathrm{~mm}$ in diameter, purity 99.99\%) were purchased from KAIT Electronic Material Co., Ltd, China. SnBiE was made of $\mathrm{Sn}-\mathrm{Bi}$ alloy wires $(2 \mathrm{~cm})$ encapsulated in Teflon with a copper wire for the conduction. To obtain a smooth and bright surface, the SnBiE was polished using aqueous alumina slurry $(0.3$ and $0.05 \mu \mathrm{m})$ and then was washed with deionized water and acetone thoroughly before use.

\section{Analytical procedures}

The analysis of $\mathrm{Fe}(\mathrm{III})$ was performed in $0.1 \mathrm{M}$ acetate buffer $(\mathrm{pH}$ 4.5) containing $2 \mu \mathrm{M}$ PAN as a complexing agent. This involved two main steps, including accumulation and stripping out. First, Fe(III)-PAN complex was accumulated onto the surface of $\mathrm{SnBiE}$ under a potential of $-0.3 \mathrm{~V} v s$. $\mathrm{Ag} / \mathrm{AgCl}$ for $60 \mathrm{~s}$ with stirring. After an equilibration period of $10 \mathrm{~s}$, the stripping voltammetry was carried out from $-0.3 \mathrm{~V}$ to $-0.54 \mathrm{~V}$ at increments of $0.004 \mathrm{~V}$ by differential pulse voltammetry (DPV).

\section{Results and discussion}

\section{Cyclic voltammetry}

The voltammetric behaviors of Fe(III)-PAN based on the SnBiE were studied in $0.1 \mathrm{M}$ acetate buffer solution ( $\mathrm{pH} 4.5$ ). The potential range was from $-0.55 \mathrm{~V}$ to $-0.25 \mathrm{~V}$. As shown in Fig. 1, SnBiE showed a low background current, and no signal was observed for the solution containing $2 \mu \mathrm{M}$ PAN in the absence of $\mathrm{Fe}^{3+}$ (curve a). The reduction peak of free PAN was not obtained in the potential range on the $\mathrm{SnBiE}$, which is different from the previous report, ${ }^{26}$ suggesting that $\mathrm{SnBiE}$ has better advantages for $\mathrm{Fe}^{3+}$ determination than BiFE. After the addition of $30 \mathrm{nM}$ $\mathrm{Fe}^{3+}$, a cathodic peak of $\mathrm{Fe}(\mathrm{III})-\mathrm{PAN}$ was obtained at $-0.47 \mathrm{~V}$ (curve b) during the negative scan. No evident peaks were observed in the positive scan, suggesting that the reduction of the complex is an irreversible process. Here, one point that needs to be stated is that the reduction of Fe(III)-PAN was carried out on a partly oxidized $\mathrm{SnBiE}$ because the oxidation peak of $\mathrm{Sn}$ at $\mathrm{SnBiE}$ in $\mathrm{pH} 4.5$ is $-0.6 \mathrm{~V}$. During the accumulation and determination of Fe(III)-PAN on the surface of the SnBiE, the competitive oxidation of $\mathrm{Sn}$ from $\mathrm{Sn}-\mathrm{Bi}$ alloy occurred simultaneously. Considering $\mathrm{Sn}$ could not be thoroughly oxidized in such a short time (about $90 \mathrm{~s}$ ), the surface of SnBiE was partly oxidized.

\section{Effect of pH and concentration of the acetate buffer}

As $\mathrm{Fe}^{3+}$ is easily hydrolyzed in slightly acidic and alkaline environments and as the formation and stability of the Fe(III)PAN complex are strongly dependent on the $\mathrm{pH}$ of solution, as well as the fact that Sn-Bi alloy can be dissolved in a strong 


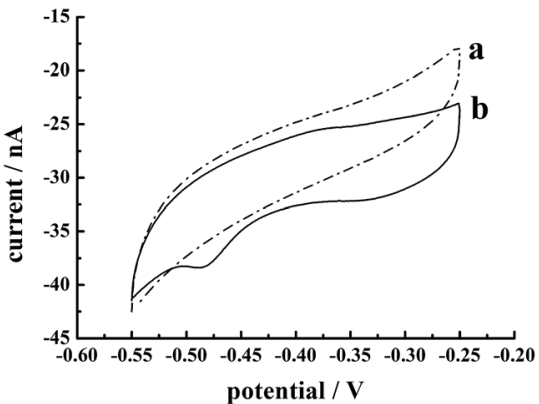

Fig. 1 Cyclic voltammograms of the SnBiE in $0.1 \mathrm{M}$ acetate buffer $(\mathrm{pH}$ 4.5) containing $2 \mu \mathrm{M}$ PAN in the absence (curve a) and presence (curve b) of $30 \mathrm{nM} \mathrm{Fe}^{3+}$, with an accumulation potential of $-0.3 \mathrm{~V}$, an accumulation time of $60 \mathrm{~s}$, and a scan rate of $50 \mathrm{mV} \mathrm{s}^{-1}$.

acidic solution, the $\mathrm{pH}$ values of the buffer solution are controlled in the medium acidity. The influence of the $0.1 \mathrm{M}$ acetate buffer's $\mathrm{pH}$ on the cathodic signals of the complex was investigated in the range from 3.5 to 5.5. As shown in Fig. 2(a), the maximum peak current of the complex was obtained at $\mathrm{pH}$ 4.5 , and the peak current decreased gradually at a lower $\mathrm{pH}$ value, which is probably due to the high background current caused by the hydrogen dissolving. Moreover, the peak current decreased with the $\mathrm{pH}$ values above 4.5 , which was probably due to the decomposition of the Fe(III)-PAN complex. Fig. 2(b) shows the results obtained from the measurements carried out in different concentrations of acetate buffer, which varied from $0.01 \mathrm{M}$ to $0.3 \mathrm{M}$. The results showed that $0.1 \mathrm{M}$ acetate buffer presented the highest cathodic peak current, because the buffer
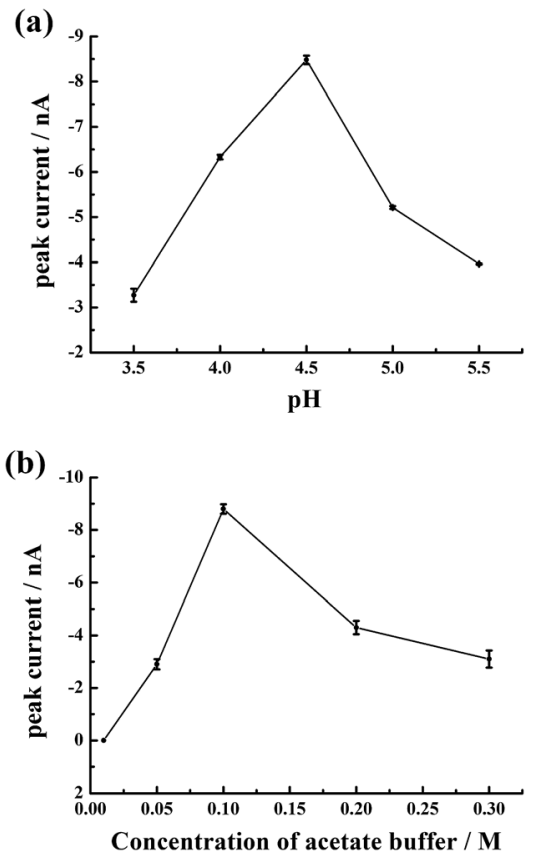

Fig. 2 Effect of the $\mathrm{pH}$ of the $0.1 \mathrm{M}$ acetate buffer solution (a) and the concentration of acetate buffer (b) on the peak current of the Fe(III)PAN complex at the $\operatorname{SnBiE}(n=3)$. Conditions: $30 \mathrm{nM} \mathrm{Fe}^{3+}, 2 \mu \mathrm{M}$ PAN; with an accumulation potential of $-0.3 \mathrm{~V}$, and an accumulation time of $60 \mathrm{~s}$. concentration which is too high or too low may influence the ionic strength. Therefore, $0.1 \mathrm{M}$ acetate buffer at $\mathrm{pH} 4.5$ was selected as the optimum experimental condition. The relationship between the peak potential $\left(E_{\mathrm{p}}\right)$ and $\mathrm{pH}$ was also investigated. $E_{\mathrm{p}}$ was shifted in a negative direction when the $\mathrm{pH}$ increased from 3.5 to 5.5, and the linear regression equation was $E_{\mathrm{p}}=-0.057 \mathrm{pH}-0.184\left(R^{2}=0.963\right)$. According to the Nernstian theory, the slope of $57 \mathrm{mV} \mathrm{pH}^{-1}$ was close to the

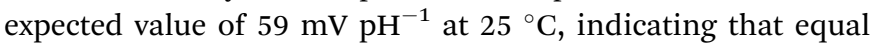
numbers of protons and electrons were involved. ${ }^{36}$

\section{Effect of the accumulation potential}

The signal due to the stripping of Fe(III)-PAN complex based on the SnBiE was studied over different accumulation potentials (Fig. 3). As shown in Fig. 3, the signal was nearly 0 A when the accumulation potential was set to $-0.6 \mathrm{~V}$, because the set potential caused the reduction of $\mathrm{Fe}(\mathrm{III})-\mathrm{PAN}$ to $\mathrm{Fe}(\mathrm{II})-\mathrm{PAN}$. Then, the peak current increased when the potential varied from $-0.6 \mathrm{~V}$ to $-0.3 \mathrm{~V}$ probably due to the positive charged complex being strongly adsorbed on the negative charged surface of the SnBiE. Moreover, the peak current decreased at a potential more positive than $-0.3 \mathrm{~V}$ because the given potentials could not fully negatively charge the surface of the SnBiE to adsorb enough Fe(III)-PAN complex. The optimum accumulation potential was chosen to be $-0.3 \mathrm{~V}$, and this value was used in all the following measurements.

\section{Effect of accumulation time}

The amount of the Fe(III)-PAN complex accumulated at the surface of the $\mathrm{SnBiE}$ is related to the accumulation time, and thus the effect of accumulation time on the peak current was studied in the range between $10 \mathrm{~s}$ and $300 \mathrm{~s}$, as illustrated in Fig. 4. It can be seen that the peak current of the complex increased rapidly as the accumulation time increased to $120 \mathrm{~s}$ and then tended to increase slowly. Though a longer accumulation time can improve the sensitivity, a short accumulation time of $60 \mathrm{~s}$ was chosen as a good compromise between the sensitivity and time of analysis for the following studies.

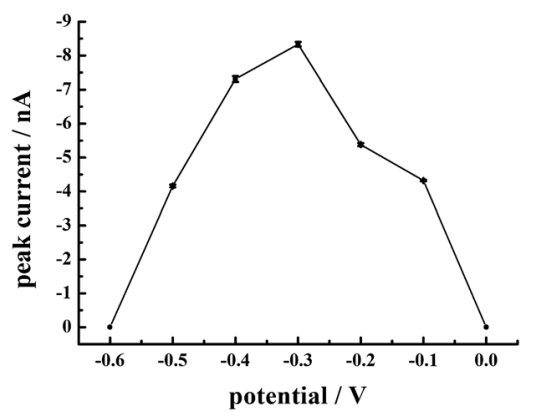

Fig. 3 Effect of accumulation potential on the stripping peak current of Fe(III)-PAN complex $(n=3)$. Conditions: a supporting electrolyte of $0.1 \mathrm{M}$ acetate buffer $(\mathrm{pH} 4.5)$ containing $2 \mu \mathrm{M}$ PAN and $30 \mathrm{nM} \mathrm{Fe}^{3+}$. The other conditions are the same as in Fig. 2. 


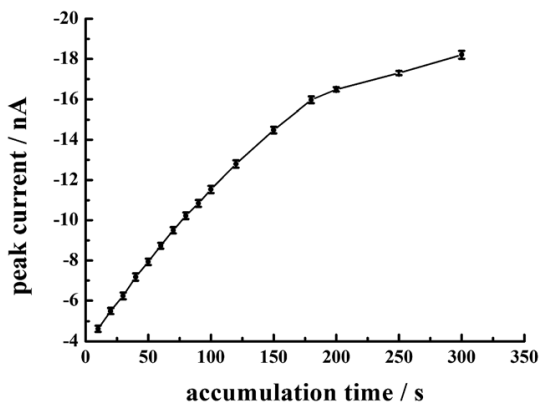

Fig. 4 Effect of accumulation time on the peak current of the Fe(III)PAN complex $(n=3)$. Conditions: a supporting electrolyte of $0.1 \mathrm{M}$ acetate buffer $(\mathrm{pH} 4.5)$ containing $2 \mu \mathrm{M}$ PAN and $30 \mathrm{nM} \mathrm{Fe}^{3+}$. The other conditions are the same as in Fig. 2.

\section{Effect of the concentration of PAN}

The concentration of PAN affects the peak current of the complex greatly, and thus its effect on the voltammetric response of the complex was examined in the range of 0.5 to 7 $\mu \mathrm{M}$ in $0.1 \mathrm{M}$ acetate buffer containing $30 \mathrm{nM} \mathrm{Fe}^{3+}$. From Fig. 5, the maximum peak current was obtained for $2 \mu \mathrm{M}$. The concentrations of PAN lower than $2 \mu \mathrm{M}$ were too dilute to have enough deposition points. For higher concentrations of PAN, a significant decrease was obtained, owing to competitive adsorption between PAN and Fe(III)-PAN complex on the electrode. Moreover, the voltammetric curves were broader than those at low concentrations of PAN. Thus, the optimum PAN concentration was chosen as $2 \mu \mathrm{M}$.

\section{Effect of scan rate}

To obtain the kinetic parameters, the effect of the scan rate with the current peak of the Fe(III)-PAN complex was studied from 5 to $200 \mathrm{mV} \mathrm{s}^{-1}$ by linear sweep voltammetry. The peak current increased linearly with the increasing scan rate, and the equation was calculated as $i_{\mathrm{p}}=-0.068 v-1.59\left(R^{2}=0.988\right)$, indicating that it is a typical adsorption-controlled process. In addition, the relationship between the peak potential and $\log v$ was found to be $E_{\mathrm{p}}=-0.112 \log v-0.47\left(R^{2}=0.955\right)$, suggesting it is an irreversible process.

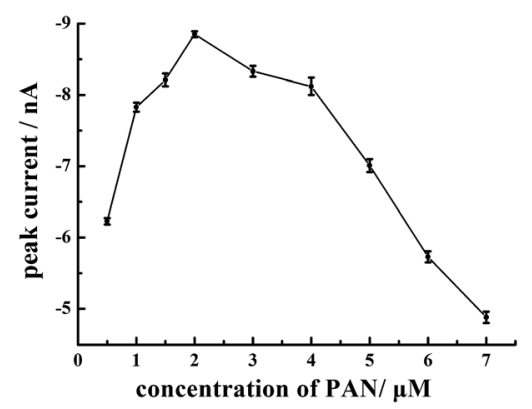

Fig. 5 Effect of the concentrations of PAN on the peak current of 30 $\mathrm{nM} \mathrm{Fe}{ }^{3+}$ in $0.1 \mathrm{M}$ acetate buffer $(\mathrm{pH} 4.5)(n=3)$. The other conditions are the same as in Fig. 2.

\section{Calibration curve, detection limit and reproducibility}

The calibration curve for the determination of $\mathrm{Fe}(\mathrm{III})$ at the SnBiE was established under the optimal conditions mentioned above (Fig. 6). For $60 \mathrm{~s}$ accumulation time, a linear relationship between the cathodic peak current and the concentration of $\mathrm{Fe}^{3+}$ was obtained in the range of $1 \mathrm{nM}$ to $900 \mathrm{nM}$ with a regression equation expressed as $i_{\mathrm{p}}=-0.124 C-5.42\left(R^{2}=\right.$ 0.995). The detection limit of $\mathrm{Fe}^{3+}$ for $60 \mathrm{~s}$ accumulation was calculated to be $0.2 \mathrm{nM}(s / n=3)$, which is lower than that at the BiFE using PAN as the complexant ${ }^{26}$ and BiFE using TEA and $\mathrm{BrO}_{3}{ }^{-}$as the complexant and catalytic agent, respectively. ${ }^{27}$ In addition, the linear range is considerably wider than the two methods based on the BiFE mentioned above. Furthermore, the detection limit of $\mathrm{Fe}^{3+}$ on our environmentally friendly $\mathrm{SnBiE}$ is lower than most mercury electrodes and other modified carbon electrodes, ${ }^{15}$ which shows that our SnBiE has a significant advantage in iron determination. The RSD of repeatability was calculated to be $3.7 \%$ based on the six successive determinations of $30 \mathrm{nM} \mathrm{Fe}{ }^{3+}$, and the RSD of reproducibility was $4.3 \%$ according to the six independent SnBiEs' determinations.

\section{Interferences study}

The influence of possible interfering species was studied by adding various foreign species into $0.1 \mathrm{M}$ acetate buffer $(\mathrm{pH}$ 4.5) containing $100 \mathrm{nM} \mathrm{Fe}{ }^{3+}$ and $2 \mu \mathrm{M}$ PAN under the optimized experimental conditions. The interfering species were added at different concentrations until they produced a $5 \%$ change in the initial peak current. The results showed that 50fold $\mathrm{Cd}^{2+}, \mathrm{Cr}^{3+}, \mathrm{Hg}^{2+}, \mathrm{As}^{3+}$ and $\mathrm{Ag}^{+}, 30$-fold $\mathrm{Ni}^{2+}, \mathrm{Pb}^{2+}$ and $\mathrm{Al}^{3+}$, 20 -fold $\mathrm{Zn}^{2+}, \mathrm{Cu}^{2+}$ and $\mathrm{Mg}^{2+}$, and 10 -fold $\mathrm{Mn}^{2+}$ and $\mathrm{Co}^{2+}$ had no influence on the peak current; this agreed with the previous reports that such metal ions cannot form stable complexes with PAN under $\mathrm{pH} 4.5$, and most of their reduction peak potentials were not in the given potential range. ${ }^{37-40}$ This suggests that the organic species in natural waters can be absorbed on the surface of the electrode or can be chelated with iron and that the surface active substances have a profound effect on the stripping responses on BiFEs, ${ }^{41}$ which cause the evident changes of current response. The influence

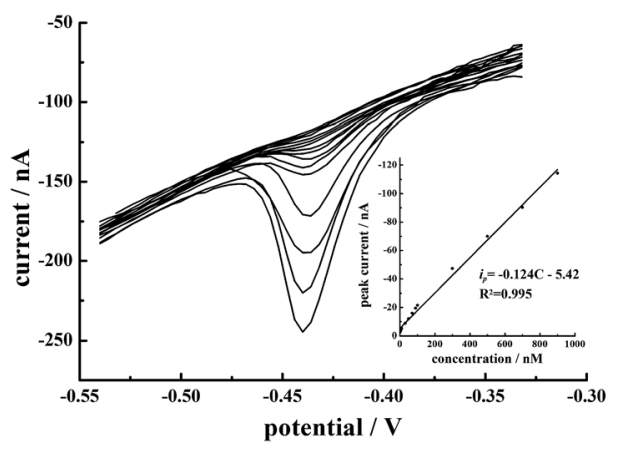

Fig. 6 Voltammetric responses of $\mathrm{Fe}^{3+}$ at the $\mathrm{SnBiE}$, where the concentrations of $\mathrm{Fe}^{3+}$ are from $1 \mathrm{nM}$ to $900 \mathrm{nM}$ in $0.1 \mathrm{M}$ acetate buffer solution containing $2 \mu \mathrm{M}$ PAN. Inset is the calibration curve of $\mathrm{Fe}^{3+}$ in the linear range. The other conditions are the same as in Fig. 2. 
of HS, EDTA, SDBS, CTAB has also been studied. Adding 20fold CTAB, 10-fold SDBS, HS and EDTA significantly decreases the peak currents, but the signals return to the original values after UV-digestion because all the organic substances have been destroyed. Moreover, our method did not interfere with the addition of $\mathrm{NaCl}$ at a concentration lower than $0.01 \mathrm{M}$, so the effect of salinity was under control because the real sample analysis was carried out in acetate buffer after at least 50-times dilution. To better eliminate the influences for real seawater samples, standard addition method was used.

\section{Practical applications}

To evaluate the practical applications of the established method based on the novel SnBiE, the total dissolved iron of the river water and seawater samples were analyzed using the standard addition method. The UV-digested water samples were diluted 1000 times for detection under the optimal conditions. The adsorptive cathodic stripping voltammetries of the digested seawater sample at the SnBiE are shown in Fig. 7. The concentration of total dissolved iron can be calculated from the fitted curve (inset of Fig. 7), and we find that the result is consistent with the data obtained by ICP-MS, which shows that the SnBiE exhibits good performance for iron determination in seawater. Moreover, to better illustrate its accuracy in practical analysis, the results obtained by this method and by ICP-MS are compared in Table 1 . The data were in a good accordance, indicating the capability of the SnBiE for iron determination in real water samples.

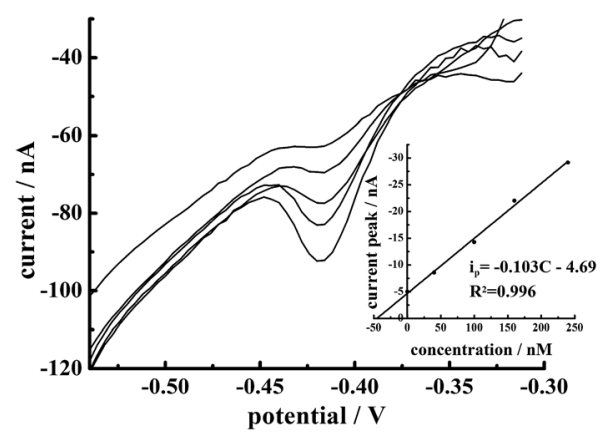

Fig. 7 Voltammetric responses of $\mathrm{Fe}^{3+}$ in a seawater sample at the $\mathrm{SnBiE}$ using the standard addition method of standard additions of 0 , $40,100,160$, and $240 \mathrm{nM} \mathrm{Fe}^{3+}$ (from top to bottom). The inset is the fitted curve of the $\mathrm{Fe}^{3+}$ measurement obtained from the standard addition. Conditions: $0.1 \mathrm{M}$ acetate buffer $(\mathrm{pH} 4.5), 2 \mu \mathrm{M}$ PAN. The other conditions are same as in Fig. 2.

Table 1 Comparison of the established method and ICP-MS for determination of total dissolved iron in real water samples $(n=3)$

\begin{tabular}{lll}
\hline Samples & $\begin{array}{l}\text { Detected by this } \\
\text { method }(\mu \mathrm{M})\end{array}$ & $\begin{array}{l}\text { Detected by } \\
\text { ICP-MS }(\mu \mathrm{M})\end{array}$ \\
\hline Coastal river water 1 & $23.8 \pm 2.3$ & $24.3 \pm 2.4$ \\
Coastal river water 2 & $44.0 \pm 3.2$ & $43.2 \pm 3.1$ \\
Coastal sea water & $45.9 \pm 2.2$ & $45.4 \pm 2.7$
\end{tabular}

\section{Conclusions}

The SnBiE was successfully used for the determination of total dissolved iron in real water samples with good accuracy and precision. Compared with the methods based on the bismuthfilm electrode, the established method based on SnBiE has several advantages such as easy fabrication, no requirement for any pretreatment, a more suitable potential range, wider linearity and a lower detection limit for iron determination. This method based on $\mathrm{SnBiE}$ will be of great benefit to investigate the effects of iron in aquatic biogeochemistry.

\section{Acknowledgements}

This work was financially supported by the National Natural Science Foundation of China (41276093), the Youth Innovation Promotion Association (2011170), and the Outstanding Young Scientists Program of CAS.

\section{Notes and references}

1 J. H. Martin, S. E. Fitzwater and R. M. Gordon, Global Biogeochem. Cycles, 1990, 4, 5-12.

2 M. J. Behrenfeld, A. J. Bale, A. S. Kolber, J. Aiken and P. G. Falkowski, Nature, 1996, 383, 508-511.

3 R. Crichton and J. R. Boelaert, Inorganic Biochemistry of Iron Metabolism: From Molecular Mechanisms to Clinical Consequences, John Wiley and Sons, Chichester, England, 2001.

4 K. H. Coale, K. S. Johnsons, S. E. Fitzwater, R. M. Gordon, S. J. Tanner, F. P. Chavez, L. Ferioli, C. Sakamoto, P. Rogers, F. J. Millero, P. Steinberg, P. Nightingale, D. Cooper, W. P. Cochlan, M. R. Landry, J. Constantinou, G. Rollwagen, A. Trasvina and R. Kudela, Nature, 1996, 383, 495-501.

5 J. H. Martin and S. E. Fitzwater, Nature, 1988, 331, 341-343. 6 A. L. Rose and T. D. Waite, Aquat. Sci., 2003, 65, 375-383.

7 W. Sunda and S. A. Huntsman, Mar. Chem., 1995, 50, 189206.

8 M. L. Wells, Limnol. Oceanogr., 1991, 38, 1379-1395.

9 D. A. Hutchins, G. R. DiTullio, Y. Zhang and K. W. Bruland, Limnol. Oceanogr., 1998, 43, 1037-1054.

10 S. Berman, J. McLaren and S. Willie, Anal. Chem., 1980, 52, 488-492.

11 J. Wu and E. A. Boyle, Anal. Chim. Acta, 1998, 367, 183-191.

12 R. M. Boiteau, J. N. Fitzsimmons, D. J. Repeta and E. A. Boyle, Anal. Chem., 2013, 85, 4357-4362.

13 M. Grotti, M. L. Abelmoschi, F. Soggia and R. Frache, Anal. Bioanal. Chem., 2003, 375, 242-247.

14 M. Grotti, F. Soggia, F. Ardini and R. Frache, J. Anal. At. Spectrom., 2009, 24, 522-527.

15 M. Lu, N. V. Rees, A. S. Kabakaev and R. G. Compton, Electroanalysis, 2012, 24, 1693-1702.

16 J. Wang, Analytical electrochemistry, Wiley, New York, 3rd edn,2006.

17 C. M. G. Van den Berg, Sci. Total Environ., 1986, 49, 89-99. 
18 A. E. Witter, B. L. Lewis and G. W. Luther III, Deep Sea Res., Part II, 2000, 47, 1517-1539.

19 T. Nagai, A. Imai, K. Matsushige, K. Yokoi and T. Fukushima, Limnology, 2004, 5, 87-94.

20 P. L. Croot and M. Johansson, Electroanalysis, 2000, 12, 565576.

21 C. M. G. van den Berg, Anal. Chem., 2006, 78, 156-163.

22 L. M. Laglera, J. Santos-Echeandía, S. Caprara and D. Monticelli, Anal. Chem., 2013, 85, 2486-2492.

23 J. Wang, J. Lu, B. Hocevar and P. A. M. Farias, Anal. Chem., 2000, 72, 3218-3222.

24 J. Wang and J. Lu, Electrochem. Commun., 2000, 2, 390-393.

25 J. Wang, J. Lu, U. A. Kirgoz, S. B. Hocevar and B. Ogorevc, Anal. Chim. Acta, 2001, 434, 29-34.

26 R. Segura, M. I. Toral and V. Arancibia, Talanta, 2008, 75, 973-977.

27 A. Bobrowski, K. Nowak and J. Zarębski, Anal. Bioanal. Chem., 2005, 382, 1691-1697.

28 A. Królicka and A. Bobrowski, Electrochem. Commun., 2004, 6, 99-104.

29 W. W. Zhu, N. B. Li and H. Q. Luo, Talanta, 2007, 72, 17331737.

30 Toxicological profile for tin and tin compounds, U.S. Department of Health and Human Services, Public Health
Service, Agency for Toxic Substances and Disease Registry, August 2005, http://www.atsdr.cdc.gov/toxprofiles\tp55.pdf.

31 Y. Q. Tian, N. B. Li and H. Q. Luo, Electroanalysis, 2009, 21, 2584-2589.

32 E. Czop, A. Economou and A. Bobrowski, Electrochim. Acta, 2011, 56, 2206-2212.

33 C. H. Xiong, H. Q. Luo and N. B. Li, J. Electroanal. Chem., 2011, 65, 19-23.

34 D. Pan, L. Zhang, J. Zhuang, T. Yin and W. Qin, Microchim. Acta, 2012, 177, 59-66.

35 D. Pan, L. Zhang, J. Zhuang, W. Lu, R. Zhu and W. Qin, Mater. Lett., 2012, 68, 472-474.

36 R. S. Nicholson, Anal. Chem., 1965, 37, 1351-1355.

37 L. Yiheng and W. Wenzhong, Metall. Anal., 1995, 15, 13-16.

38 J. Vuković, S. Matsuoka, K. Yoshimura, V. Grdinić, R. J. Grubešić and O. Županić, Talanta, 2007, 71, 2085-2091.

39 A. Corsini, I. M. Yih, Q. Fernando and H. Freiser, Anal. Chem., 1962, 34, 1090-1093.

40 A. Mohadesi, Z. Motallebi and A. Salmanipour, Analyst, 2010, 135, 1686-1690.

41 J. Wang, R. P. Deo, S. Thongngamdee and B. Ogorevc, Electroanalysis, 2001, 13, 1153-1156. 